Tạp chí Khoa học và Công nghệ biển T11 (2011). Số 4. Tr 35 - 46

\title{
ẢNH HƯởNG CỦA CÁC NGUỒN THẢI ĐẾN MÔI TRƯờNG NƯớC ĐẦM TH!̣ NẠI
}

\author{
LÊ THỊ VINH, NGUYẼ̃N THỊ THANH THỦY
}

Viện Hải dương học

\begin{abstract}
Tóm tắt: Các nguồn thải ảnh hưởng đến chất luợng môi truờng đầm Thị Nai hiện nay chủ yếu là tù sinh hoạt dân cu. Chất thải này cùng với vật chất tù sông Kôn đã gây ra tình trạng uu duỡng với nồng độ các muối dinh duỡng (đặc biệt là ammonia, nitrate và phosphate), chất hũu co cao và nồng độ oxy hòa tan tuoong đối thấp trong khu vục tù đỉnh đầm đến cồn Chim. Đặc biệt mật độ vi sinh gây bệnh, nhất là coliform, đã ở mức rất cao trong toàn đầm. Ở khu vưc Tây Nam đầm nuơóc thải tù̀ sinh hoạt dân cu và chế biến thủy sản với nồng độ các chất dinh duõng, hũu co cao, nhu cầu oxy lớn và đặc biệt là mật độ vi khuẩn cung rất cao chỉ có tác động đáng kể đối với khu vục tiếp nhận. Hoạt động nuôi trồng thủy sản (NTTS) xung quanh đầm cũng làm gia tăng nhu cầu oxy, nồng độ của các chất dinh duõ̃ng (đặc biệt là các hợp chất chứa phospho) và mật độ vi sinh.
\end{abstract}

\section{MỞ ĐÀ̀U}

Đầm Thị Nại là đầm lớn thứ hai trong số các đầm phá ở Việt Nam sau hệ đầm phá Tam Giang - Cầu Hai và có tiềm năng to lớn về nuôi trồng và khai thác thủy sản. Hai hoạt động này đã và đang là kế sinh nhai của hàng ngàn hộ dân quanh đầm, góp phần đáng kể vào tăng trưởng kinh tế chung của địa phương. Việc gia tăng khai thác nguồn lợi và nuôi trồng thủy sản một cách ồ ạt cùng với việc đầm phải tiếp nhận các chất thải từ sinh hoạt dân cư, công nghiệp ... và các nguồn vật chất từ tự nhiên bởi 2 con sông Kôn và Hà Thanh đã làm phát sinh một số vấn đề về môi trường. Vào mùa khô, khu vực đỉnh đầm Thị Nại đã rơi vào tình trạng ưu dưỡng kèm theo nồng độ oxy hòa tan khá thấp. Bên cạnh đó, mật độ vi sinh gây bệnh cũng rất lớn, nồng độ $F e$ cũng cao trong toàn đầm vào cả 2 mùa mưa (11/2008) và mùa khô $(4 / 2009)$ (Lê Thị Vinh và Nguyễn Thị Thanh Thủy, 2009).

Bài báo này đã xem xét tác động của các nguồn thải từ hoạt động con người đối với môi trường đầm Thị Nại. Đây là một trong các kết quả nghiên cứu của nhiệm vụ "Nghiên cứu $c o$ " sở khoa học nhằm xây dựng các giải pháp phát triển nuôi trồng thủy sản bền vũng tại đầm Thị Nại, tỉnh Bình Định"được Viện Hải dương học thực hiện trong hai năm 2008 - 2009. 


\section{PHƯONG PHÁP NGHIÊN CÚU}

35 mẫu nước thải từ các hoạt động kinh tế - xã hội đã được thu tại các cống thải trong khu vực dân cư đổ trực tiếp và gián tiếp (qua sông Hà Thanh) vào đầm vào các thời điểm khác nhau (từ tháng 11/2008 đến 8/2009). Nước từ 9 ao nuôi tôm quanh đầm cũng được thu và phân tích vào mùa vụ chính (4 - 5/2009). 24 mẫu nước sông Kôn (chảy vào đỉnh đầm) và Hà Thanh (chảy vào Tây Nam đầm) cũng được thu vào mùa mưa (tháng 11 , 12/2008) và mùa khô (tháng 4 - 8/2009) để ước tính lượng vật chất từ sông đổ vào đầm. Vị trí các nguồn thải và ao nuôi được trình bày ở hình 1 . Bên cạnh đó, các số liệu dân số năm 2008, tải lượng nước sông, nước thải cũng được thu thập.

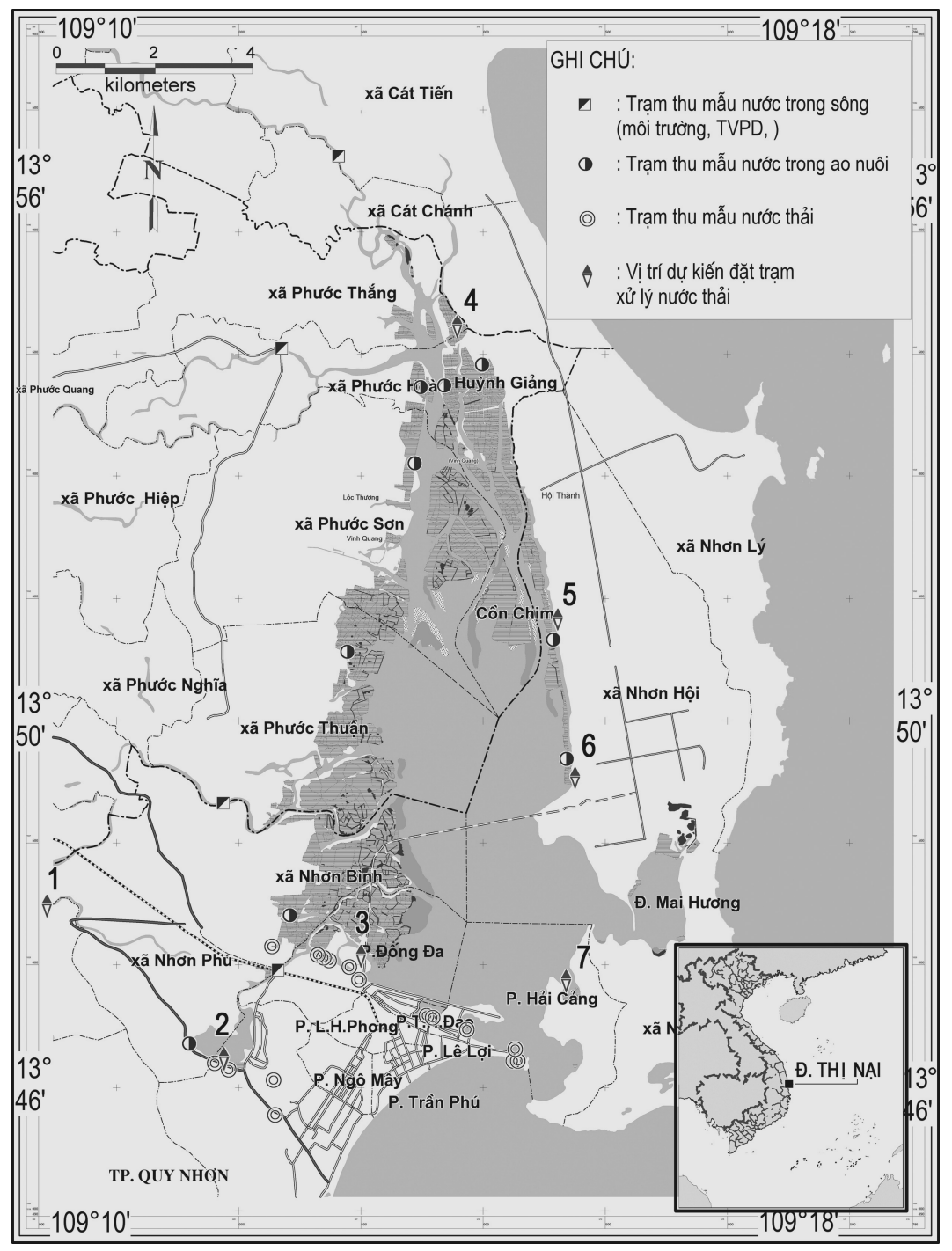

Hình 1: Vị trí các trạm thu mẫu 
Các chỉ tiêu phân tích gồm:

Mẫu thải và ao nuôi: $\mathrm{pH}, \mathrm{BOD}_{5}, \mathrm{COD}$, vật lơ lửng (TSS), muối dinh dưỡng, các chất hữu cơ và vi khuẩn gây bệnh.

Mẫu nước sông:Vật lơ lửng, $\mathrm{BOD}_{5}, \mathrm{COD}$, muối dinh dưỡng, chất hữu cơ, $\mathrm{Fe}$ và vi khuẩn gây bệnh (coliform, E.coli và Vibrio).

Các mẫu nước thải, ao nuôi, mẫu nước sông được thu, xử lý, bảo quản và phân tích theo APHA, 2005.

Ước tính tải lượng ngày đêm của các chất gây ô nhiễm do các hộ dân thải ra đầm được tính theo Tổ chức y tế Thế giới (WHO), 1993.

\section{KẾT QUẢ NGHIÊN CÚU}

\section{Các nguồn thải từ các hoạt động kinh tế - xã hội đổ vào đầm Thị Nại}

Các hoạt động kinh tế xã hội đang có ảnh hưởng đến môi trường đầm phân bố theo các khu vực sau: (1) phía Bắc đầm; (2) phía Tây Nam đầm; (3) Đông Nam đầm; (4) dân cư Cồn Chim. Ngoài ra còn có hoạt động nuôi trồng thủy sản chung quanh đầm.

1. Khu vực phía Bắc đầm bao gồm các xã Phước Sơn, Phước Hòa, Phước Thắng, Cát Chánh, Nhơn Lý. Tại các xã này, nước thải được đổ trực tiếp hoặc gián tiếp vào đầm (không theo các cống thải). Nhiều hộ dân không có nhà vệ sinh nên thải trực tiếp vào đầm. Theo tính toán, tổng dân số các xã ven bờ phía Bắc đầm Thị Nại vào khoảng 15.797 người. Do nhiều hộ dân cư sống xa đầm, giả định khoảng 20\% số người này (3.000 người) đưa chất thải trực tiếp vào đầm, tải lượng các chất gây ô nhiễm do các xã thuộc khu vực phía Bắc đưa vào đầm Thị Nại được ước tính trong bảng 1 .

Bảng 1: Ước tính tải lượng các chất gây ô nhiễm do các hộ dân thải ra đầm

\begin{tabular}{|c|c|c|c|c|c|}
\hline Thông số & BOD $_{\mathbf{5}}$ & TSS & Tổng $\mathbf{~}$ & $\mathbf{N H}_{\mathbf{3}, \mathbf{4}} \mathbf{- N}$ & Tổng $\mathbf{P}$ \\
\hline Giá trị trung bình (g/người/ngày)* & 49,5 & 107 & 9 & 3,6 & 2,4 \\
\hline $\begin{array}{c}\text { Tải lượng chất gây ô nhiểm } \\
\text { (kg/ngày) }\end{array}$ & 148,5 & 321 & 27 & 10,8 & 7,2 \\
\hline
\end{tabular}

* Theo WHO, 1993.

2. Khu vực phía Tây Nam đầm gồm xã Phước Thuận và một số phường liền kề đầm của thành phố Qui Nhơn. 
* Nước thải sinh hoạt: Tại thành phố Qui Nhơn, hệ thống thoát nước được sử dụng để thoát cả nước thải trong đó có cả từ các hộ dân và nước mưa (Công ty Nước và Môi trường Việt Nam, 2005). Hệ thống này có hướng thoát nước về sông Hà Thanh và đầm Thị Nại. Tiếp giáp trực tiếp với đầm Thị Nại về phía Tây Nam là xã Nhơn Bình và 3 phường Đống Đa, Hải Cảng, Thị Nại. Các mẫu thải tại các cống thải thuộc 3 phường này đã được thu và phân tích (bảng 2).

Kết quả phân tích cho thấy các chất gây nhiễm bẩn có nồng độ rất cao (nhất là vật lơ lửng, muối dinh dưỡng và chất hữu cơ). Các giá trị $\mathrm{BOD}_{5}$ trong mẫu nước thải cũng lớn, đặc biệt mật độ vi khuẩn gây bệnh cũng rất cao. Nước thải thuộc phường Hải Cảng có nhiều chất gây nhiễm bẩn nhất. So với QCVN 14: 2008/BTNMT có thể thấy nồng độ vật lơ lửng, $\mathrm{BOD}$, ammonia, phosphate trong nước thải có lúc cao hơn các giới hạn cho phép (GHCP). Mật độ coliform luôn vượt GHCP rất nhiều (có lúc gấp hàng chục triệu lần).

Mặc dù có nhiều dẫn liệu về thành phần nước thải nhưng do không có dẫn liệu về lưu lượng nên tải lượng các chất gây ô nhiễm được ước tính thông qua dân số. Tổng dân số của các xã phường (Phước Thuận, Nhơn Phú, Hải Cảng, Nhơn Bình, Trần Hưng Đạo, Thị Nại, Đống Đa, Hải Cảng, Quang Trung) trong phần Tây Nam đầm là 127.602 người. Do nhiều dân cư sống sát đầm, có nhiều cống thải đưa vào đầm, giả định là $40 \%$ số người này đưa chất thải trực tiếp vào đầm. Theo cách ước tính như đối với khu vực Bắc đầm, tải lượng (ngày-đêm) các chất gây ô nhiễm do sinh hoạt dân cư tại phần Tây Nam đầm khá lớn (2.526 kg BOD $5,5.461 \mathrm{~kg}$ vật lơ lửng, $459 \mathrm{~kg} \mathrm{~N}, 184 \mathrm{~kg}$ ammonia, $122 \mathrm{~kg} \mathrm{P}$ tổng).

* Nước thải công nghiệp: nước thải công nghiệp tại thành phố Qui Nhơn chủ yếu là từ hoạt động của 2 cơ sở chế biến thủy sản. Nước thải của 2 cơ sở này đã có nồng độ các chất gây ô nhiễm vượt quá các GHCP qui định trong QCVN 24:2009/BTNMT, nhất là nước thải từ nhà máy đông lạnh Qui Nhơn (bảng 3). Tải lượng các chất gây ô nhiễm từ các cơ sở sản xuất được ước tính trong bảng 4 (giả định nước thải chợ cá có thành phần giống nước thải Công ty Thủy sản Bình Định, nước thải cảng tính theo WHO, 1993 với lượng người tính từ lượng nước thải 100 1/người/ngày). 
Bảng 2: Giá trị thống kê thành phần nước thải đổ ra đầm Thị Nại

a. Các thông số cơ bản, yếu tố dinh dưỡng.

\begin{tabular}{|c|c|c|c|c|c|c|c|c|c|c|}
\hline Giá trị & pH & $\begin{array}{l}\text { TSS } \\
\mathrm{mg} / \mathrm{l}\end{array}$ & $\begin{array}{c}\mathrm{BOD}_{5} \\
\mathrm{Mg} / \mathrm{l}\end{array}$ & $\begin{array}{l}\text { COD } \\
\mathrm{mg} / \mathrm{l}\end{array}$ & $\begin{array}{c}\mathrm{NH}_{3,4}-\mathrm{N} \\
\mu \mathrm{g} / \mathrm{l}\end{array}$ & $\begin{array}{c}\mathrm{NO}_{2}-\mathrm{N} \\
\mu \mathrm{g} / \mathrm{l}\end{array}$ & $\begin{array}{c}\mathrm{NO}_{3}-\mathrm{N} \\
\mu \mathrm{g} / \mathrm{l}\end{array}$ & $\begin{array}{l}\text { Nhc } \\
\mu \mathrm{g} / \mathrm{l}\end{array}$ & $\begin{array}{c}\mathrm{PO}_{4}-\mathrm{P} \\
\mu \mathrm{g} / \mathrm{l}\end{array}$ & $\begin{array}{l}\text { P hc } \\
\mu \mathrm{g} / \mathrm{l}\end{array}$ \\
\hline \multicolumn{11}{|c|}{ Phường Đống Đa, đổ ra sông Hà Thanh } \\
\hline TB & 7,00 & 182,1 & 56,4 & 101,1 & 2151 & 73,5 & 1.285 & 21.821 & 2.383 & 14.514 \\
\hline $\mathrm{CT}$ & 6,45 & 33,0 & 12,2 & 22,7 & 325 & 0 & 62 & 3174 & 418 & 1.356 \\
\hline $\mathrm{C} \bigoplus$ & 7,57 & 531,0 & 208,1 & 381,5 & 4480 & 628,8 & 6.854 & 73.110 & 6.960 & 67.248 \\
\hline $\mathrm{n}$ & 14 & 14 & 11 & 14 & 14 & 14 & 14 & 14 & 14 & 14 \\
\hline \multicolumn{11}{|c|}{ Phường Thị Nại (khu vực chọ̣ Đầm), đổ trực tiếp vào đầm } \\
\hline TB & 7,15 & 89,9 & 84,1 & 115,8 & 1.188 & 30,4 & 230 & 74.799 & 2.945 & 53.203 \\
\hline $\mathrm{CT}$ & 6,93 & 71,8 & 33,9 & 50,0 & 98 & 0 & 97 & 47.920 & 2.000 & 29.488 \\
\hline $\mathrm{C} \bigoplus$ & 7,39 & 122,4 & 131,2 & 205,0 & 2.480 & 44,5 & 426 & 102.060 & 4.440 & 79.812 \\
\hline $\mathrm{n}$ & 4 & 4 & 4 & 4 & 4 & 4 & 4 & 4 & 4 & 4 \\
\hline \multicolumn{11}{|c|}{ Phường Hải Cảng, đổ trực tiếp vào đầm } \\
\hline TB & 6,92 & 293,6 & 98,9 & 131,8 & 5.967 & 180 & 3.522 & 88.502 & 8.015 & 65.414 \\
\hline $\mathrm{CT}$ & 6,40 & 36,2 & 16,9 & 40,0 & 60 & 0 & 66 & 1568 & 612 & 2.713 \\
\hline $\mathrm{CÐ}$ & 7,44 & 1611 & 240,5 & 356,5 & 42.590 & 2.410 & 13.891 & 327.423 & 43.800 & 257.400 \\
\hline $\mathrm{n}$ & 17 & 17 & 12 & 17 & 17 & 17 & 17 & 17 & 17 & 17 \\
\hline \multicolumn{11}{|c|}{ QCVN 14: 2008/BTNMT (nước thải sinh hoạt thải vào nguồn nước không dùng cho sinh hoạt) } \\
\hline Cột B & $5-9$ & 100 & 50 & - & 10.000 & & 50.000 & - & 10.000 & - \\
\hline
\end{tabular}

b. Mật độ vi khuẩn

\begin{tabular}{|c|c|c|c|c|}
\hline Địa điểm & Giá trị & $\begin{array}{c}\text { Coliform } \\
\text { MPN/100 ml }\end{array}$ & $\begin{array}{c}\text { E. coli } \\
\text { MPN/100 ml }\end{array}$ & $\begin{array}{c}\text { Vibrio } \\
\text { TB/100 ml }\end{array}$ \\
\hline \multirow[t]{4}{*}{ Phường Đống Đa } & TB & 66.566 .228 .571 & 109.171 .429 & 702.929 \\
\hline & $\mathrm{CT}$ & 1.500 .000 & 1.100 .000 & 252.500 \\
\hline & $\mathrm{C} \bigoplus$ & 460.000 .000 .000 & 460.000 .000 & 1.470 .000 \\
\hline & $\mathrm{n}$ & 7 & 7 & 7 \\
\hline \multirow[t]{4}{*}{ Phường Thị Nại } & TB & 10.850 .000 .000 & 81.950 .000 & 500.000 \\
\hline & $\mathrm{CT}$ & 240.000 .000 & 2.400 .000 & 280.000 \\
\hline & $\mathrm{C} \bigoplus$ & 15.000 .000 .000 & 230.000 .000 & 860.000 \\
\hline & $\mathrm{n}$ & 4 & 4 & 4 \\
\hline \multirow[t]{4}{*}{ Phường Hải Cảng } & TB & 137.965 .201 .250 & 11.230 .143 & 1.304 .063 \\
\hline & $\mathrm{CT}$ & 110.000 & 11.000 & 34.000 \\
\hline & $\mathrm{C} \bigoplus$ & 1.100 .000 .000 .000 & 29.000 .000 & 4.260 .000 \\
\hline & $\mathrm{n}$ & 8 & 7 & 8 \\
\hline QCVN 14: 2008/BTNMT, cột B & & 5.000 & & \\
\hline
\end{tabular}

TB: trung bình, CĐ: cục đại, $C T$ : cưc tiểu, $n$ : số mẫu 
Bảng 3: Thành phần nước thải của 2 cơ sở chế biến thủy sản chính của Qui Nhơn

\begin{tabular}{|c|c|c|c|c|c|c|c|}
\hline Địa điểm & $\mathbf{p H}$ & $\begin{array}{l}\text { TSS } \\
(\mathrm{mg} / \mathrm{l})\end{array}$ & $\begin{array}{l}\text { BOD }_{5} \\
(\mathrm{mg} / \mathrm{l})\end{array}$ & $\begin{array}{l}\text { COD } \\
(\mathrm{mg} / \mathrm{l})\end{array}$ & $\begin{array}{r}\text { Tổng N } \\
(\mathrm{mg} / \mathrm{l})\end{array}$ & $\begin{array}{r}\text { Tổng P } \\
(\mathrm{mg} / \mathrm{l})\end{array}$ & $\begin{array}{c}\text { Coliform } \\
\text { (MPN/100 ml) }\end{array}$ \\
\hline \multicolumn{8}{|c|}{ Đông lạnh Qui Nhơn (thải $100 \mathrm{~m}^{3} / \mathrm{ngày)}$} \\
\hline $7 / 2008$ & 7,56 & 145 & 259,1 & 316 & 38,7 & 7,79 & 5300 \\
\hline \multicolumn{8}{|c|}{ Thủy sản Bình Định (thải 100 m³/ngày) } \\
\hline $5 / 2008$ & 6,72 & 56,0 & 58,0 & 146 & 20,4 & 6,2 & $2,4 \times 10^{6}$ \\
\hline $8 / 2008$ & 4,97 & 56,4 & 62,0 & 136 & 1,4 & 7,2 & $9,3 \times 10^{3}$ \\
\hline $12 / 2008$ & 7,33 & 32,0 & 46,7 & 64,6 & 39,7 & 1,8 & $2,4 \times 10^{4}$ \\
\hline $\begin{array}{l}\text { QCVN } 24 \text { :2009/ } \\
\text { BTNMT, cột B }\end{array}$ & $5,5-9,0$ & 100 & 50 & 100 & 30 & 6 & 5000 \\
\hline
\end{tabular}

Nguồn: Sở Tài nguyên và Môi trường, tỉnh Bình Định

Bảng 4: Ước tính tải lượng các chất gây ô nhiễm từ các hoạt động sản xuất phía Tây Nam đầm Thị Nại

\begin{tabular}{|c|c|c|c|c|c|c|}
\hline Địa điểm & $\begin{array}{l}\text { TSS } \\
\text { kg }\end{array}$ & $\begin{array}{c}\text { BOD }_{5} \\
\text { kg }\end{array}$ & $\begin{array}{c}\text { COD } \\
\mathrm{kg}\end{array}$ & $\begin{array}{c}\text { Tổng N } \\
\text { kg }\end{array}$ & $\begin{array}{c}\text { Tổng P } \\
\text { kg }\end{array}$ & $\begin{array}{c}\text { Coliform } \\
\text { MPN/100 ml }\end{array}$ \\
\hline $\begin{array}{l}\text { Đông lạnh Qui Nhơn (100 } \\
\qquad \text { m³ } 3 \text { ngày) }^{3}\end{array}$ & 14,5 & 25,91 & 31,6 & 3,87 & 0,779 & 530 \\
\hline $\begin{array}{l}\text { Thủy sản Bình Định (100 } \\
\text { m³/ngày) }\end{array}$ & 4,8 & 5,60 & 11,6 & 2,1 & 0,5 & 81.110 \\
\hline Chợ cá (50 m³/ngày) & 7,2 & 12,95 & 15,8 & 1,93 & 0,39 & 265 \\
\hline $\begin{array}{c}\text { Cảng B. Định, Q.Nhơn (50 } \\
\left.\mathrm{m}^{3} / \text { ngày }\right)\end{array}$ & 53,5 & 24,75 & - & 4,5 & 1,2 & - \\
\hline Tổng & 80,1 & 69,2 & 59,0 & 12,4 & 2,9 & 81.905 \\
\hline
\end{tabular}

3. Khu vực phía Đông Nam đầm: gồm xã Nhơn Hội (4.028 người) và Nhơn Hải (1.200 người). Theo báo cáo của Sở Tài nguyên Môi trường, có một số nơi ở xã Nhơn Hội, khu vệ sinh theo ống thải thẳng ra đầm. Do không thu được mẫu nước thải tại khu 
vực này nên tải lượng các chất thải được ước tính qua dân số. Cũng theo cách ước tính như trên, khoảng $40 \%$ lượng chất thải đổ vào đầm thì tải lượng (ngày-đêm) các chất gây ô nhiễm đổ vào phía Đông $\mathrm{Nam}$ đầm là $99 \mathrm{~kg} \mathrm{BOD}$, $214 \mathrm{~kg}$ vật lơ lửng, $18 \mathrm{~kg} \mathrm{~N}, 7,2 \mathrm{~kg}$ $\mathrm{NH}_{3,4}-\mathrm{N}, 4,8 \mathrm{~kg}$ P.

4. Khu dân cư Cồn Chim: Tại khu vực Cồn Chim, trong số 159 hộ (800 dân), chỉ có $9,4 \%$ số hộ có nhà vệ sinh nên có thể nói là đây là một trong các nguyên nhân gây nên sự nhiễm bẩn vi sinh ở mức độ đáng báo động trong đầm Thị Nại. Tại khu vực này, do tỉ lệ các hộ dân có nhà vệ sinh rất ít, do vậy ước tính $90 \%$ dân số (720 người) thải trực tiếp ra đồng. Lượng các chất ô nhiễm từ khu dân cư Cồn Chim đổ vào đầm Thị Nại sẽ là: 73,7 kg Vật lơ lửng, 34,1 kg BOD $5,6,2$ kg N, 2,48 kg NH $3,4-\mathrm{N}, 1,58$ kg P.

\section{2. Ảnh hưởng của các nguồn thải đến chất lượng môi trường đầm}

Bảng 5: Tổng tải lượng (ngày-đêm) các chất gây ô nhiễm đổ vào đầm Thị Nại

\begin{tabular}{|c|c|c|c|c|c|c|c|c|c|c|}
\hline Khu vực & $\begin{array}{c}\text { Vật } \\
\text { LL } \\
\text { (tấn) }\end{array}$ & $\begin{array}{l}\text { BOD }_{5} \\
(\mathrm{~kg})\end{array}$ & $\begin{array}{l}\text { COD } \\
(\mathrm{kg})\end{array}$ & $\begin{array}{c}\mathrm{NH}_{3,4^{-}} \\
\mathbf{N} \\
(\mathbf{k g})\end{array}$ & $\begin{array}{c}\mathrm{NO}_{2^{-}} \\
\mathrm{N} \\
(\mathrm{kg})\end{array}$ & $\begin{array}{c}\mathrm{NO}_{3^{-}} \\
\mathrm{N} \\
(\mathrm{kg})\end{array}$ & \begin{tabular}{|c|} 
Tổng \\
$\mathrm{N}$ \\
$(\mathrm{kg})$ \\
\end{tabular} & $\begin{array}{c}\mathrm{PO}_{4}- \\
\mathbf{P} \\
(\mathrm{kg})\end{array}$ & $\begin{array}{c}\text { Tổng } \\
\text { P } \\
\text { (kg) }\end{array}$ & $\begin{array}{l}\mathrm{Fe} \\
(\mathrm{kg})\end{array}$ \\
\hline \multicolumn{11}{|l|}{ Khu vực đỉnh đầm } \\
\hline Khu dân cư phía Bắc đầm & 321 & 149 & - & 10,8 & - & - & 27 & - & 7,2 & - \\
\hline Khu dân cư Cồn Chim & 73,7 & 34,1 & - & 2,5 & - & - & 6,2 & - & 1,6 & - \\
\hline Sông Kôn mùa khô & 141 & 10.175 & 80252 & 537 & 53 & 1.378 & 5.889 & 156 & 615 & 5.032 \\
\hline Sông Kôn mùa mưa & 1.280 & 28.475 & 326.481 & 1.433 & 471 & 3.613 & 21326 & 499 & 2.148 & 35.357 \\
\hline Tổng lượng mùa khô & 536 & 10.358 & 80.252 & 550 & 53 & 1.378 & 5.916 & 156 & 624 & 5.032 \\
\hline Tổng lượng mùa mưa & 1.675 & 28.658 & 326.481 & 1446 & 471 & 3.613 & 21.353 & 499 & 2.157 & 35.357 \\
\hline $\begin{array}{l}\text { Khu vực Tây Nam } \\
\text { Dân cư phía Tây Nam }\end{array}$ & 5.461 & 2.526 & - & 184 & - & - & 459 & - & 122 & - \\
\hline Công Nghiệp & 80 & 69 & 59 & - & - & - & 12.4 & - & 2.9 & - \\
\hline S. Hà Thanh mùa khô & 25 & 2.503 & 15.078 & 64 & 6 & 170 & 937 & 24 & 124 & 778 \\
\hline S. Hà Thanh mùa mưa & 427 & 5.250 & 60.417 & 190 & 55 & 311 & 3.346 & 47 & 367 & 6.245 \\
\hline Tổng lượng mùa khô & 5.566 & 5.098 & 15.137 & 248 & 6 & 170 & 1.408 & 24 & 249 & 778 \\
\hline Tổng lượng mùa mưa & 5.968 & 7.845 & 60.476 & 374 & 55 & 311 & 3.817 & 47 & 492 & 6245 \\
\hline \multicolumn{11}{|l|}{ Khu vụcc Đông Nam } \\
\hline Dân cư & 214 & 99 & - & 7,2 & - & - & 18 & 4,8 & - & - \\
\hline
\end{tabular}


Tổng tải lượng các chất gây ô nhiễm theo các khu vưc đỉnh đầm, khu vực Tây Nam và khu vực Đông Nam đầm được ước tính trong bảng 5 . Cần lưu ý là tải lượng các chất gây ô nhiễm từ nuôi trồng chưa được tính. Ngoài ra tải lượng các chất gây ô nhiễm từ các sông cũng được xem xét vì đây là tác nhân có thể can thiệp làm thay đổi tác động của các hoạt động con người.

Các dẫn liệu trong bảng 5 cho thấy nguồn các chất gây ô nhiễm lớn nhất là vật chất từ các sông và chất thải sinh hoạt. So với lượng vật chất từ sông Kôn, lượng chất thải từ sinh hoạt ở khu vực đỉnh đầm có tổng lượng bằng khoảng $1 / 4$ vào mùa mưa và lớn hơn vào mùa khô. Trong lúc đó lượng vât chất từ sinh hoạt ở phần Tây Nam đầm lớn hơn lượng vật chất từ sông Hà Thanh vào cả 2 mùa. Có thể nói là trong mùa mưa vật chất từ sông có ảnh hưởng nhiều đến chất lượng môi trường khu vực đỉnh đầm trong lúc chất thải sinh hoạt có ảnh hưởng lớn hơn đến chất lượng môi trường khu vực Tây Nam đầm. Vào mùa khô, vai trò của chất thải từ hoạt động con người quan trọng ở cả hai khu vực nói trên.

Để có cái nhìn rõ hơn về ảnh hưởng của nước thải sinh hoạt đến môi trường nước đầm, nồng độ các yếu tố gây ô nhiễm trong nước sông, nước thải và nước đầm được so sánh trong bảng 6. Qua đó có thể thấy vào mùa mưa nước thải sinh hoạt có những tác động nhất định đến nồng độ oxy hòa tan, nhu cầu oxy, các chất dinh dưỡng, đặc biệt là ammonia và các hợp chất của phospho (giá trị $\mathrm{COD}$ của nước thải cao hơn nước đầm khoảng 3 lần, giá trị của nitrite, nitrat, $\mathrm{N}$ hữu cơ của nước thải cao hơn so với nước đầm khoảng chục lần, đặc biệt giá trị của amonia, phosphat, $\mathrm{P}$ hữu cơ của nước thải cao hơn so với nước đầm hơn 100 lần). Vào mùa khô, nước thải sinh hoạt tác động đến môi trường nước đầm cao hơn so với mùa mưa (giá trị vật lơ lửng, $\mathrm{COD}$ trong nước thải cao gấp 6 lần so với nước đầm, nồng độ của muối dinh dưỡng chứa nitơ trong nước thải cao hơn hàng chục lần so với nước đầm; nồng độ của phosphate, $\mathrm{N}$ hữu cơ, và đặc biệt là $\mathrm{P}$ hữu cơ trong nước thải cao hơn nước đầm hàng trăm lần). Về chỉ tiêu vi sinh, có thể thấy tác động của nước thải sinh hoạt đối với nước đầm rất lớn (mật độ của coliform, $E$. coli trong nước thải cao hơn so với nước đầm có thể tới hàng trăm ngàn lần và hàng chục lần đối với Vibrio, bảng 7). Đối với kim loại $\mathrm{Fe}$, vai trò của chất thải sinh hoạt không quan trọng, nồng độ cao của $\mathrm{Fe}$ chủ yếu từ sông Kôn và Hà Thanh đưa ra (bảng 7).

Như vậy, có thể nói là ở tình trạng hiện nay, chất thải từ sinh hoạt có tác động chủ yếu đến nồng độ vật lơ lửng, chất hữu cơ, muối dinh dưỡng và mật độ vi sinh (coliform, E.coli và Vibrio) trong nước, nhất là tại khu vực đỉnh đầm. Tác động của nước thải sinh hoạt về mặt dinh dưỡng có thể làm thay đổi cân bằng của tỉ số mol N/P trong đầm, nhất là vào mùa khô (tỉ số $\mathrm{N} / \mathrm{P}$ trung bình trong nước thải sinh hoạt là 7,51 , thấp hơn rất nhiều so với nước đầm là 43,50). 
Bảng 6: So sánh giá trị trung bình các yếu tố trong nước sông, nước thải và nước đầm

\begin{tabular}{|c|c|c|c|c|c|c|c|c|c|c|c|}
\hline Thò̀i gian & $\mathbf{p H}$ & $\begin{array}{c}\text { TSS } \\
(\mathrm{mg} / \mathrm{l})\end{array}$ & $\begin{array}{c}\text { DO } \\
(\mathrm{mg} / \mathrm{l})\end{array}$ & $\begin{array}{c}\text { BOD } \\
(\mathrm{mg} / \mathrm{l})\end{array}$ & $\begin{array}{l}\text { COD } \\
(\mathrm{mg} / \mathrm{l})\end{array}$ & $\begin{array}{c}\mathrm{NO}_{2}-\mathrm{N} \\
(\mu \mathrm{g} / \mathrm{l})\end{array}$ & $\begin{array}{c}\mathrm{NO}_{3}-\mathrm{N} \\
(\mu \mathrm{g} / \mathrm{l})\end{array}$ & $\begin{array}{c}\mathrm{NH}_{3.4}-\mathrm{N} \\
(\mu \mathrm{g} / \mathrm{l})\end{array}$ & $\begin{array}{c}\text { N h. co } \\
(\mu \mathrm{g} / \mathrm{l})\end{array}$ & $\begin{array}{c}\mathrm{PO}_{4}-\mathrm{P} \\
(\mu \mathrm{g} / \mathrm{l})\end{array}$ & $\begin{array}{c}\text { P h. co } \\
(\mu \mathrm{g} / \mathrm{l})\end{array}$ \\
\hline \multicolumn{12}{|c|}{ Mùa mưa: tháng 11-2008 } \\
\hline S. Kôn & 6,69 & 95,0 & 7,53 & 0,73 & 15,3 & 29,7 & 114 & 28,5 & 726 & 8,45 & 80,8 \\
\hline Đỉnh đầm & 7,16 & 86,6 & 6,75 & 0,84 & 17,4 & 7,2 & 63 & 38,4 & 593 & 18,7 & 47,9 \\
\hline Hà Thanh & 6,76 & 102,4 & 7,30 & 1,3 & 14,5 & 13,3 & 75 & 45,5 & 670 & 11,2 & 77 \\
\hline Thải & 6,77 & 90,7 & - & - & 47,8 & 128 & 2005 & 6008 & 10187 & 2813 & 6215 \\
\hline Giữa đầm & 7,47 & 59,7 & 7,01 & 1,24 & 19,3 & 5,7 & 47 & 28,1 & 590 & 12,8 & 40,8 \\
\hline Cửa đầm & 7,56 & 49,2 & 6,88 & 1,09 & 18,7 & 6,2 & 43 & 14,8 & 661 & 12,7 & 34,8 \\
\hline \multicolumn{12}{|c|}{ Mùa khô: tháng 4-2009 } \\
\hline S. Kôn & 7,21 & 23,6 & 5,38 & 1,70 & 13,45 & 8,9 & 231 & 90 & 656,5 & 26,15 & 76,9 \\
\hline Đỉnh đầm & 7,27 & 30,9 & 4,98 & 1,15 & 16,8 & 6,0 & 172 & 110 & 658 & 24,4 & 50,4 \\
\hline Hà Thanh & 7,50 & 23,9 & 6,41 & 2,41 & 14,5 & 5,7 & 162 & 61 & 670,5 & 22,85 & 96,1 \\
\hline Thải & 7,03 & 245 & - & 61,35 & 107 & 127 & 2466 & 2695 & 53225 & 4138 & 42145 \\
\hline Giữa đầm & 8,02 & 39,5 & 6,10 & 1,29 & 17,9 & 0,5 & 36 & 26,4 & 604 & 3,1 & 40,6 \\
\hline Cửa đầm & 7,95 & 35,6 & 6,09 & 0,96 & 16,8 & 1,2 & 44 & 28 & 621 & 4,4 & 26,7 \\
\hline
\end{tabular}

Khu vực đỉnh đầm: tù đỉnh đầm đến Cồn Chim, sông Kôn đổ vào, khu vực này rất hẹp; Khu vực giũ̃a đầm: có diện tích mở rộng hơn và chịu ảnh huởng trục tiếp của nuớc sông Hà Thanh; Phía cứa đầm: có sụ trao đổi với biển khơi

Tác động môi trường của hoạt động nuôi thủy sản (NTTS): Nước ao nuôi có thể ảnh hưởng đến nhu cầu oxy, nồng độ của các chất dinh dưỡng (đặc biệt là phosphat và $\mathrm{P}$ hữu cơ) và mật độ vi sinh do giá trị của các yếu tố này trong nước ao tương đối cao hơn so với nước đầm $\left(\mathrm{BOD}_{5}, \mathrm{NH}_{3,4}\right.$, phosphate, $\mathrm{N}$ hữu cơ và $\mathrm{P}$ hữu cơ trong nước ao nuôi cao hơn cỡ 2-5 lần so với nước đầm; Coliform, $E$. coli và Vibrio cao hơn cỡ hàng chục lần, bảng 8). Theo kết quả điều tra của đề tài, trong năm 2008, tại đầm Thị Nại diện tích nuôi ao nuôi tương đối lớn (khoảng 1.393,7 ha), sản lượng tôm nuôi khá cao (tôm sú: 763,2 tấn, tôm chân trắng: 59,5 tấn). Các dẫn liệu này cho thấy là hoạt động NTTS cũng có ảnh hưởng nhất định tới chất lượng nước đầm. 
Bảng 7: Nồng độ trung bình Fe và vi sinh ở các khu vực trong sông và đầm

\begin{tabular}{|c|c|c|c|c|c|}
\hline Thò̀i gian & Vị trí & $\begin{array}{c}\text { Fe } \\
(\boldsymbol{\mu g} / \mathbf{l})\end{array}$ & $\begin{array}{c}\text { Coliform } \\
(\mathbf{M P N} / 100 ~ \mathbf{~ m})\end{array}$ & $\begin{array}{c}\text { E. coli } \\
(\mathbf{M P N} / \mathbf{1 0 0} \mathbf{~ m l})\end{array}$ & $\begin{array}{c}\text { Vibrio } \\
\mathbf{( T B / 1 0 0} \mathbf{~ m l})\end{array}$ \\
\hline $11-2008$ & Sông Kôn & 1.801 & 60.500 & 4.600 & 11.800 \\
\hline (Mùa mưa) & Đỉnh đầm & 1.083 & 41.867 & 4.287 & 4.767 \\
\hline & Sông Hà Thanh & 1.499 & 4.600 & 3.500 & 4.100 \\
\hline & Nuớc thải & - & 220.786 .092 .000 & 113.250 .600 & 251.000 \\
\hline & Giữa đầm & 718 & 7.175 & 2.170 & 1.750 \\
\hline $4-2009$ & Cửa đầm & 494 & 84.167 & 80.620 & 36.767 \\
\hline Sông Kôn & 842 & 26.825 & 7.323 & 6.750 \\
\hline & Đỉnh đầm & 607 & 25.300 & 6.550 & 8.200 \\
\hline & Sông Hà Thanh & 747 & 8.800 & 3.807 & 6.000 \\
\hline & Nước thải & - & 55.389 .894 .706 & 40.756 .029 & 1.132 .588 \\
\hline & Giữa đầm & 233 & 113 & 27 & 3.550 \\
\hline & Cửa đầm & 217 & 297 & 132 & 33.800 \\
\hline
\end{tabular}

Dưới tác động của các nguồn thải (bao gồm cả vật chất từ sông), trong khu vực đỉnh đầm đã có hiện tượng thiếu oxy hòa tan $(<5 \mathrm{mg} / \mathrm{l})$ vào mùa khô, nồng độ trung bình của phosphate, nitrate và Fe đã vượt quá các GHCP $(15 \mu \mathrm{gP} / 1,60 \mu \mathrm{gN} / 1$ và $100 \mu \mathrm{gFe} / \mathrm{l})$ qui định trong tiêu chuẩn Asean và QCVN 10: 2008/BTNMT đối với nước thủy sản vào cả 2 mùa. Mật độ colliform trong nước đầm cũng cao hơn GHCP (1000 MPN/100 ml) qui định trong QCVN 10: 2008 rất nhiều, nhất là trong khu vực đỉnh đầm và vào mùa mưa (bảng 6 và 7). Ở khu vực Tây Nam đầm chất thải chỉ có tác động đáng kể đối với khu vực nhỏ sát bờ và các nhánh sông, hồ tiếp nhận nước thải như hồ Đống Đa, cảng cá Hà Thanh, cảng cá Hàm Tử. Tại các vị trí này nồng độ oxy hòa tan thấp, muối dinh dưỡng và các chất hữu cơ cao, mật độ coliform cũng rất lớn (Lê Thị Vinh và Nguyễn Thị Thanh Thủy, 2009). 
Bảng 8: So sánh thành phần nước ao nuôi và nước đầm

a. Các thông số cơ bản và mật độ vi khuẩn

\begin{tabular}{|c|c|c|c|c|c|c|c|}
\hline \multirow[t]{2}{*}{ Khu vụ̣c } & \multirow[t]{2}{*}{$\mathbf{p H}$} & \multirow{2}{*}{$\begin{array}{c}\text { TSS } \\
(\mathrm{mg} / \mathrm{l})\end{array}$} & \multirow{2}{*}{$\begin{array}{l}\text { BOD }_{5} \\
(\mathrm{mg} / \mathrm{l})\end{array}$} & \multirow{2}{*}{$\begin{array}{l}\text { COD } \\
(\mathrm{mg} / \mathrm{l})\end{array}$} & $\begin{array}{c}\text { Colifor } \\
\mathbf{m}\end{array}$ & E. coli & \multirow{2}{*}{$\begin{array}{c}\text { Vibrio } \\
\text { TB/100 ml }\end{array}$} \\
\hline & & & & & \multicolumn{2}{|c|}{ MPN/100 ml } & \\
\hline Ao đỉnh đầm & 7,30 & 40,8 & 6,0 & 20,7 & 406.106 & 97.786 & 56.940 \\
\hline Đỉnh đầm 11-2008 & 7,16 & 86,6 & 0,84 & 17,4 & 41.867 & 4.287 & 4.767 \\
\hline Đỉnh đầm 4-2009 & 7,27 & 30,9 & 1,15 & 16,8 & 25.300 & 6.550 & 8.200 \\
\hline Ao phía Đông đầm & 7,70 & 38,2 & 5,4 & 21,7 & 5.615 & 483 & 4.650 \\
\hline Giữa đầm 11-2008 & 7,47 & 59,7 & 1,24 & 19,3 & 7.175 & 2.170 & 1.750 \\
\hline Giữa đầm 4-2009 & 8,02 & 39,5 & 1,29 & 17,9 & 113 & 27 & 3.550 \\
\hline
\end{tabular}

b. Yếu tố dinh dưỡng

\begin{tabular}{|c|c|c|c|c|c|c|}
\hline Khu vực & $\begin{array}{c}\mathbf{N H}_{\mathbf{3}, \mathbf{4}}-\mathbf{N} \\
\boldsymbol{\mu g} / \mathbf{l}\end{array}$ & $\begin{array}{c}\mathbf{N O}_{\mathbf{2}}-\mathbf{N} \\
\boldsymbol{\mu g} / \mathbf{l}\end{array}$ & $\begin{array}{c}\mathbf{N O}_{\mathbf{3}}-\mathbf{N} \\
\boldsymbol{\mu g} / \mathbf{l}\end{array}$ & $\begin{array}{c}\mathbf{N h c} \\
\boldsymbol{\mu g} / \mathbf{l}\end{array}$ & $\begin{array}{c}\mathbf{P O}_{\mathbf{4}}-\mathbf{P} \\
\boldsymbol{\mu g} / \mathbf{l}\end{array}$ & $\begin{array}{c}\mathbf{P h c} \\
\boldsymbol{\mu g} / \mathbf{l}\end{array}$ \\
\hline Ao đỉnh đầm & 183 & 8,3 & 167 & 1.057 & 42,0 & 132 \\
\hline Đỉnh đầm 11-2008 & 38,4 & 7,2 & 63 & 593 & 18,7 & 47,9 \\
\hline Đỉnh đầm 4-2009 & 110 & 6,0 & 172 & 658 & 24,4 & 50,4 \\
\hline Ao phía Đông đầm & 38,7 & 0,5 & 192 & 1.239 & 120 & 170,7 \\
\hline Giữa đầm 11-2008 & 28,1 & 5,7 & 47 & 590 & 12,8 & 40,8 \\
\hline Giữa đầm 4-2009 & 26,4 & 0,5 & 36 & 604 & 3,1 & 40,6 \\
\hline
\end{tabular}

\section{KẾT LUẬN}

Chất thải từ các hoạt động con người, phần lớn là từ sinh hoạt dân cư cùng với vật chất từ sông Kôn đã làm giảm nồng độ oxy hòa tan, tăng cao nhu cầu oxy, nồng độ vật lơ lửng, chất hữu cơ và các muối dinh dưỡng, đặc biệt là các chất dinh dưỡng chứa phospho và vi sinh (coliform, E.coli và Vibrio trong khu vực đỉnh đầm, đặc biệt là vào mùa khô). Ở khu vực Tây Nam đầm, chất thải chỉ có tác động cục bộ đối với một số khu vực nhỏ sát bờ. Hoạt động nuôi trồng thủy sản có thể làm tăng cao nhu cầu oxy và nồng độ của các chất dinh dưỡng cũng như mật độ vi sinh. 


\title{
TÀI LIỆU THAM KHẢO
}

1. APHA, 2005. Standard Methods for Analysis of Water and Waste Water. $21^{\text {st }}$ Edition.

2. Canadian Council of Ministers of the Environment, 2003. Marine water Quality Criteria for The ASIAN Region - Online Publication.

3. Nguyễn Tấn Hương, 2005. Đặc điểm khí tượng thuỷ văn tỉnh Bình Định. Sở Khoa học và Công nghệ tỉnh Bình Định, đài khí tượng thủy văn khu vực Nam Trung bộ.

4. Qui chuẩn Việt Nam, 2008. Bộ Tài nguyên và Môi trường.

5. Lê Thị Vinh và Nguyễn Thị Thanh Thủy, 2009. Một số vấn đề liên quan đến chất lượng môi trường nước đầm Thị Nại, tỉnh Bình Định. Kỷ yếu hội thảo khoa học công nghệ, môi trường và phát triển bền vững ở duyên hải miền Trung. 196-205.

6. Số liệu lưu trữ của Sở Tài nguyên và Môi trường tỉnh Bình Định

\section{IMPACTS OF WASTE SOURCES ON WATER ENVIRONMENT OF THI NAI LAGOON, BINH DINH}

\section{LE THI VINH, NGUYEN THI THANH THUY}

\begin{abstract}
Summary: The mainly waste sources, which impact on water environment of Thi Nai lagoon is the domestic activities. The domestic wastes together with matters from Kon river resulted in eutrophication with high levels of nutrient (especially ammonia and phosphate) organic matters and low level of dissolved oxygen from the top toward Chim hillock. Bacteria counts were very high, especially coliform in the whole lagoon. In the South West of the lagoon, the wastes from the domestic and processing activities with very high concentrations of nutrients, organic matters, bio-chemical demands and coliform count impacted considerably on the directly received areas. The aquaculture activities around the lagoon also resulted in the higher value of $\mathrm{BOD}_{5}$, nutritive substance (especially phosphor compounds) and bacteria count.
\end{abstract}

Ngày nhận bài: 25 - 8 - 2010

Ngưòi nhận xét: PGS.TSKH. Nguyễn Tác An 